\title{
Metabotropic Glutamate Receptor 5-Induced Phosphorylation of Extracellular Signal-Regulated Kinase in Astrocytes Depends on Transactivation of the Epidermal Growth Factor Receptor
}

\author{
Richard D. Peavy, ${ }^{1,2}$ Mike S. S. Chang, ${ }^{3}$ Elaine Sanders-Bush, ${ }^{3}$ and P. Jeffrey Conn ${ }^{1,4}$ \\ ${ }^{1}$ Department of Pharmacology, Emory University School of Medicine and ${ }^{2}$ Graduate Program in Molecular and Systems \\ Pharmacology, Graduate Division of Biological and Biomedical Sciences, Emory University, Atlanta, Georgia 30322, \\ ${ }^{3}$ Department of Pharmacology and Center for Molecular Neuroscience, Vanderbilt University School of Medicine, \\ Nashville, Tennessee 37232, and ${ }^{4}$ Department of Neuroscience, Merck Research Laboratories, West Point, Pennsylvania \\ 19485-0004
}

G-protein-coupled receptors (GPCRs) induce the phosphorylation of mitogen-activated protein (MAP) kinase by actions on any of a number of signal transduction systems. Previous studies have revealed that activation of the $\mathrm{G}_{\mathrm{q}}$-coupled metabotropic glutamate receptor 5 (mGluR5) induces phosphorylation of the MAP kinase extracellular signal-regulated kinase 2 (ERK2) in cultured rat cortical astrocytes. We performed a series of studies to determine the mechanisms underlying mGluR5-induced phosphorylation of MAP kinase in these cells. Interestingly, our studies suggest that mGluR5-mediated ERK2 phosphorylation is dependent on the activation of $\mathrm{G}_{\alpha q}$ but is not mediated by the activation of phospholipase $C \beta 1$, activation of protein kinase $\mathrm{C}$, or increases in intracellular calcium. Studies with peptide inhibitors suggest that this response is not depen- dent on $\mathrm{G}_{\beta \gamma}$ subunits. However, the activation of ERK2 was dependent on activation of the epidermal growth factor (EGF) receptor and activation of a Src family tyrosine kinase. Furthermore, activation of mGluR5 induced an association of this receptor and the EGF receptor, suggesting the formation of a signaling complex involved in the activation of ERK2. These data suggest that mGluR5 increases ERK2 phosphorylation in astrocytes by a novel mechanism involving the activation of $\mathrm{G}_{\alpha \mathrm{q}}$ and both receptor and nonreceptor tyrosine kinases but that is independent of the activation of phospholipase $C \beta 1$.

Key words: metabotropic glutamate receptor 5; extracellular signal-regulated kinase 2; epidermal growth factor receptor transactivation; astrocytes; $G_{q / 11}$; Src family tyrosine kinases
G-protein-coupled receptors (GPCRs) activate mitogen-activated protein (MAP) kinase signaling cascades by a wide variety of mechanisms. These include the activation of classical second messenger systems, G-protein subunits coupling to novel effectors, and receptor coupling directly to effectors independently of G-proteins. MAP kinases also are regulated tightly by receptor tyrosine kinases, and GPCRs activate MAP kinase signaling in some systems by mechanisms that involve the transactivation of receptor tyrosine kinases (Hall et al., 1999). Although the physiological roles of MAP kinase activation may be diverse, a convergence of signals resulting from GPCRs and growth factors on this pathway often leads to physiological responses associated with the activation of the mitogenic pathway, i.e., cell proliferation and differentiation. In addition, MAP kinase-dependent mechanisms of receptor desensitization and internalization via the formation of multiprotein signaling complexes have been reported (Maudsley et al., 2000).

\footnotetext{
Received June 19, 2001; revised Sept. 26, 2001; accepted Sept. 27, 2001.

This work was supported by grants from the National Institutes of Health (NIH)National Institute of Mental Health (P.J.C.), including Grants MH12398 (R.D.P.) and MH34001 (E.S.B. and M.S.S.C.), and by grants from NIH-National Institute of Neurological Diseases and Stroke (P.J.C. and R.D.P.). We thank Nancy Ciliax for her excellent technical support.

Correspondence should be addressed to Dr. P. Jeffrey Conn, Senior Director, Neuroscience, Merck Research Laboratories, Merck \& Company, Inc., 770 Sumneytown Pike, P.O. Box 4, WP 46-300, West Point, PA 19486-0004. E-mail: jeff_conn@merck.com.

M. Chang's present address: Department of Chemistry, University of Florida, Gainesville, FL 32611.

Copyright (C) 2001 Society for Neuroscience $\quad 0270-6474 / 01 / 219619-10 \$ 15.00 / 0$
}

We recently reported that the activation of metabotropic glutamate receptors (mGluRs) induces an increase in phosphorylation of the MAP kinase extracellular signal-regulated kinase 2 (ERK2) in cultured rat cortical astrocytes (Peavy and Conn, 1998). To date, eight mGluR subtypes (mGluR1-mGluR8) have been identified by molecular cloning. These receptors have been classified into three major groups on the basis of sequence homology, pharmacological profile, and coupling to G-proteins and effector systems. Group I mGluRs (mGluR1 and mGluR5) couple to the $\mathrm{G}_{\mathrm{q} / 11}$ family of G-proteins and activation of phospholipase $\mathrm{C} \beta 1$ and phosphoinositide hydrolysis. mGluRs belonging to groups II (mGluR2 and mGluR3) and III (mGluRs 4, 6, 7, and 8) couple to $G_{i / o}$ and associated effectors such as ion channels and inhibition of adenylyl cyclase (Conn and Pin, 1997). In cortical astrocytes, ERK2 phosphorylation can be induced by the group I mGluR agonist (RS)-3,5-dihydroxyphenylglycine (DHPG), but not by agonists of group II and group III mGluRs (Peavy and Conn, 1998). This, coupled with the abundant expression of mGluR5 in these cells, suggests that this response likely is mediated by mGluR5. However, mGluR1 also can activate MAP kinases in some cell types (Ferraguti et al., 1999), and an exclusive role of mGluR5 in mediating this response has not been established rigorously. Furthermore, the precise mechanism by which group I mGluRs activate ERK2 in these cells is not known. We now have taken advantage of selective agonists and antagonists for mGluR1 and mGluR5 to show that mGluR5 is responsible for the activation of ERK2 phosphorylation in cortical astrocytes. Furthermore, we have investigated the mechanism by 
which mGluR5 activates this signaling cascade. Interestingly, our studies suggest that mGluR5 induces ERK2 phosphorylation by a mechanism that is independent of the activation of phospholipase $\mathrm{C} \beta 1$ but is dependent on the activation of $\mathrm{G}_{\alpha q}$ and transactivation of the epidermal growth factor (EGF) receptor.

\section{MATERIALS AND METHODS}

Cell culture. Purified secondary astrocytic cultures were prepared by the method of McCarthy and de Vellis (1980) as modified by Miller et al. (1993). In brief, neocortices from 2- to 4-d-old Sprague Dawley rat pups were dissected and dissociated in medium by trituration. The cells were centrifuged and resuspended in DMEM supplemented with 10\% FBS, 1 $\mathrm{mm}$ sodium pyruvate, $2 \mathrm{~mm}$ L-glutamine, and PenStrep in tissue culture flasks; the medium was changed the next day. Cell cultures were maintained at $37^{\circ} \mathrm{C}$ in an atmosphere of $95 \%$ air $/ 5 \%$ carbon dioxide for $6-8$ d. At $1 \mathrm{~d}$ after overnight shaking $(280-310 \mathrm{rpm})$ to remove oligodendrocytes and microglia, the cells were trypsinized and replated into poly-Dlysine-precoated plastic multiwell plates in DMEM with $10 \%$ FBS. After $1 \mathrm{~d}$ the medium was replaced with DMEM and G-5 supplement (Life Technologies, Gaithersburg, MD) containing EGF (10 $\mathrm{ng} / \mathrm{ml})$, basic fibroblast growth factor $(5 \mathrm{ng} / \mathrm{ml})$, insulin $(5 \mu \mathrm{g} / \mathrm{ml})$, and other factors. Within $2 \mathrm{~d}$ the cells were nearly confluent and resembled the stellate appearance of astrocytes in vivo. When the cultures were used in experiments 3-5 d after adding G-5-supplemented DMEM, almost no other cell morphologies were evident. Immunostaining verified that the cultures were $>95 \%$ GFAP-positive. The day before each experiment was conducted, the medium was removed and replaced with L-glutamine-free DMEM supplemented with PenStrep.

Treatment of astrocytic cultures and preparation of samples for immunoprecipitation and gel electrophoresis. For ERK2 phosphorylation and EGF receptor phosphorylation experiments, aliquots of concentrated agonist, antagonist, or inhibitor stock solutions were added to triplicate wells and incubated at $37^{\circ} \mathrm{C}$ in an atmosphere of $95 \%$ air $/ 5 \%$ carbon dioxide. At the end of the incubation the solutions were aspirated quickly, an aliquot of cold homogenization buffer [containing (in mM) 50 Tris- $\mathrm{HCl}, 50$ $\mathrm{NaCl}, 5$ EDTA, 10 EGTA, $1 \mathrm{Na}_{3} \mathrm{VO}_{4}, 2 \mathrm{Na}_{4} \mathrm{P}_{2} \mathrm{O}_{7} \cdot 10 \mathrm{H}_{2} \mathrm{O}, 4$ magnesium para-nitrophenyl phosphate, and 1 phenylmethylsulfonyl fluoride plus 10 $\mu \mathrm{g} / \mathrm{ml}$ leupeptin and $2 \mu \mathrm{g} / \mathrm{ml}$ aprotinin] was added to each well, and the cells were frozen in liquid nitrogen. The cells were harvested, transferred to Eppendorf tubes, homogenized by brief sonication, and solubilized in SDS sample buffer. Protein concentrations were determined by the bicinchonic acid assay (Pierce, Rockford, IL), using bovine serum albumin as the standard. For immunoprecipitation experiments the cells were treated with agonists, antagonists, and inhibitors and then incubated at $37^{\circ} \mathrm{C}$ in $95 \%$ air $/ 5 \%$ carbon dioxide. At the end of the incubation the solutions were aspirated quickly, and the cells were solubilized with cold homogenization buffer with $1 \%$ Triton X-100.

Immunoblotting and quantitative densitometry. Aliquots of astrocytic homogenates containing equal amounts of protein were subjected to SDS-PAGE and transferred to Immobilon-P membranes (Millipore, Bedford, MA) by electroblotting. Blots were blocked for $1 \mathrm{hr}$ in Trisbuffered saline (TBS) and $0.1 \%$ Tween 20 (TBS-T) and incubated overnight at $4^{\circ} \mathrm{C}$ in phospho-specific (Thr ${ }^{202} / \mathrm{Tyr}^{204}$ ) p44/p42 MAP kinases (ERK1/2) antibody (1:1000) or in p44/p42 MAP kinases antibody $(1: 1000)$ or in phospho-specific $\left(\mathrm{Tyr}^{1173}\right)$ EGF receptor antibody $(1: 500)$ or EGF receptor antibody (1:1000). Blots for ERK2 phosphorylation experiments were washed with TBS-T and then with $5 \%$ nonfat milk in TBS-T, incubated for $1 \mathrm{hr}$ in horseradish peroxidase-conjugated goat anti-rabbit $\operatorname{IgG}(1: 10,000$; Bio-Rad, Hercules, CA), washed again with $5 \%$ nonfat milk in TBS-T and in TBS, and processed for immunoreactivity via enhanced chemiluminescence (Amersham Pharmacia Biotech, Uppsala, Sweden). Blots for EGF receptor phosphorylation experiments were washed with TBS-T and then with TBS, incubated for $1 \mathrm{hr}$ in horseradish peroxidase-conjugated goat anti-mouse IgG (1:3000; Bio$\mathrm{Rad})$ for phospho-specific EGF receptor or goat anti-rabbit $\operatorname{IgG}(1: 3000$; Bio-Rad) for EGF receptor, washed again with TBS-T and TBS, and processed for immunoreactivity via enhanced chemiluminescence (Amersham Pharmacia Biotech). Densitometry of immunoblots (Lynx densitometry) was used to quantify the changes in levels of ERK2 phosphorylation by comparing levels of phospho-specific ERK2 with basal levels and similarly for EGF receptor phosphorylation. Values are expressed as a percentage of basal.

Immunoprecipitation. Solubilized astrocytic cells were centrifuged at $14,000 \mathrm{rpm}$ for $10 \mathrm{~min}$. The supernatant was transferred to Eppendorf tubes and incubated with anti-mGluR5 $(4 \mu \mathrm{g} / \mathrm{ml})$ or anti-EGF receptor $(3.5 \mu \mathrm{g} / \mathrm{ml})$ overnight at $4^{\circ} \mathrm{C}$. Protein A-Sepharose beads were added and incubated at $4^{\circ} \mathrm{C}$ for $3 \mathrm{hr}$. Beads were pelleted and washed once with 50

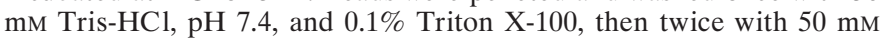
Tris- $\mathrm{HCl}$, and then pelleted again. Gel-loading sample buffer $(50 \mu \mathrm{l}, 2 \times)$ was added to the samples and incubated at room temperature for $30 \mathrm{~min}$, then boiled for $5 \mathrm{~min}$, and centrifuged for $10 \mathrm{~min}$ at 14,000 rpm. An aliquot $(35 \mu \mathrm{l})$ was taken from each sample and run on an SDSpolyacrylamide gel and then transferred to Immobilon-P membrane. Blots were blocked for $1 \mathrm{hr}$ in TBS-T (for phosphotyrosine) or for $30 \mathrm{~min}$ in $3 \%$ nonfat milk/TBS (for mGluR5 and EGF receptor) or for $30 \mathrm{~min}$ in 5\% nonfat milk/TBS (for GLT-1) and incubated overnight at $4^{\circ} \mathrm{C}$ with primary antibody for phosphotyrosine (1:2000 in TBS-T), mGluR5 (1: 1000 in 3\% nonfat milk/TBS), the EGF receptor (1:2000 in 3\% nonfat milk/TBS), or GLT-1 (1:500 in 5\% nonfat milk/TBS). Phosphotyrosine blots were washed with TBS-T and then with $5 \%$ nonfat milk in TBS-T, incubated for $1 \mathrm{hr}$ in horseradish peroxidase-conjugated goat anti-mouse $\operatorname{IgG}(1: 1000 ;$ Bio-Rad), and washed again with $5 \%$ nonfat milk in TBS-T and in TBS; mGluR5 and EGF receptor blots were washed twice with water, incubated for $1 \mathrm{hr}$ in horseradish peroxidase-conjugated goat anti-rabbit $\operatorname{IgG}(1: 10,000$; Bio-Rad), and washed again with water and TBS. GLT-1 blots were washed three times with TBS, incubated for $1 \mathrm{hr}$ in horseradish peroxidase-conjugated goat anti-guinea pig IgG (1:10,000; Chemicon, Temecula, CA), washed again with TBS, and processed for immunoreactivity via enhanced chemiluminescence (Amersham Pharmacia Biotech). Densitometry of phosphotyrosine immunoblots was used to quantify the changes in levels of phosphotyrosine compared with basal levels. Values are expressed as a percentage of basal.

Phosphoinositide hydrolysis. Phosphoinositide hydrolysis was determined by measuring the accumulation of tritiated inositol monophosphate in the presence of lithium. Astrocytes in 24-well plates were incubated for $24 \mathrm{hr}$ with $2 \mu \mathrm{Ci}$ of myo- $\left[{ }^{3} \mathrm{H}\right]$-inositol. Next the cells were washed three times with Krebs buffer [lsqb[containing (in mM) $108 \mathrm{NaCl}$, 4.7 KCl, $\left.2.5 \mathrm{CaCl}_{2} \cdot 2 \mathrm{H}_{2} \mathrm{O}, 1.2 \mathrm{MgSO}_{4} \cdot 7 \mathrm{H}_{2} \mathrm{O}, 1.2 \mathrm{KH}_{2} \mathrm{PO}_{4}\right]$ and then were incubated for $30 \mathrm{~min}$ in the presence or absence of MPS-PLC $\beta 1$ peptide inhibitor in Krebs buffer at $37^{\circ} \mathrm{C}$ in an atmosphere of $95 \%$ air $/ 5 \%$ carbon dioxide. After treatment with DHPG the solutions were aspirated, and $0.75 \mathrm{ml}$ of cold methanol was added to terminate the reaction. Cells were scraped, washed with $0.75 \mathrm{ml}$ of $\mathrm{H}_{2} \mathrm{O}$, and transferred to tubes containing $0.75 \mathrm{ml}$ of chloroform. After brief sonication and vortex mixing, the aqueous and organic phases were separated by centrif ugation at $4000 \mathrm{rpm}$ for $10 \mathrm{~min}$. An $0.75 \mathrm{ml}$ aliquot from the aqueous phase was added to anion exchange columns containing Dowex-1 (200-300 mesh in the formate form) for the separation of $\left[{ }^{3} \mathrm{H}\right]$-inositol-containing compounds. $\left[{ }^{3} \mathrm{H}\right]$-inositol monophosphate was eluted into scintillation vials and measured by liquid scintillation counting.

Calcium fluorescence measurements. Astrocytes were plated onto coverslips, treated with DMEM/G-5, and switched to L-glutamine-free DMEM the day before the experiments. The cells were washed once in a saline buffer [containing (in mM) $135 \mathrm{NaCl}, 5 \mathrm{KCl}, 1 \mathrm{MgCl}_{2}, 10$ HEPES, 25 D-glucose, $2 \mathrm{CaCl}_{2}$, pH 7.4, plus sucrose to adjust the osmolarity to that of DMEM] and then were incubated for $30 \mathrm{~min}$ in 5 $\mu \mathrm{M}$ fluo- 3 at $37^{\circ} \mathrm{C}$ in an atmosphere of $95 \%$ air $/ 5 \%$ carbon dioxide. The cells were washed again with buffer and incubated for $30 \mathrm{~min}$ in buffer with BAPTA-AM $(30 \mu \mathrm{M})$. To eliminate calcium signals generated by the release of ATP and glutamate from astrocytes and the activation of purinergic and ionotropic glutamate receptors, we added the antagonists PPADS $(100 \mu \mathrm{M})$ and CNQX $(10 \mu \mathrm{M})$ to the buffer that was used during the perfusion. Coverslips were placed in the perfusion chamber; after a baseline period ( $3 \mathrm{~min})$ of perfusion with buffer the DHPG $(100 \mu \mathrm{M}, 30$ sec) was applied, and images were acquired every $2 \mathrm{sec}$ after $25 \mathrm{msec}$ exposure to $450-490 \mathrm{~nm}$ light. Fluorescence was recorded through a bandpass filter (500-550 nm), using a Princeton MicroMax camera (Princeton Instruments, Trenton, NJ). Fluorescence intensity was measured in cell bodies via the Axon imaging workbench program (Axon Instruments, Foster City, CA) and expressed as $F / F_{\mathrm{o}}$, where $F_{\mathrm{o}}$ is the fluorescence intensity before DHPG treatment.

Materials. Chemicals and reagents were obtained from the following sources: DHPG, $(R S)$-2-chloro-5-hydroxyphenylglycine (CHPG), 2-methyl-6-(phenylethynyl)-pyridinehydrochloride(MPEP), 7-(hydroxyimino) cyclopropa[b]chromen-1a-carboxylate ethyl ester (CPCCOEt), pyridoxalphosphate-6-azophenyl-2', $4^{\prime}$-disulfonic acid tetrasodium salt (PPADS), and 6-cyano-7-nitroquinoxaline-2,3-dione disodium salt (CNQX) from Tocris-Cookson (Ballwin, MO); 1,2-bis(o-amino-5-fluorophenoxy) ethane- $N, N, N^{\prime}, N^{\prime}$-tetra(acetoxymethyl) ester (BAPTA-AM), 1-[6-((17 $\beta$ - 
3-methoxyestra-1,3,5(10)-trien-17-yl)amino)hexyl]-1H-pyrrole-2,5-dione (U73122), pertussis toxin (PTX), 4-amino-5-(4-methylphenyl)-7-( $t$-butyl) pyrazolo[3,4-d]-pyrimidine (PP1), 4-hydroxy-3-methoxy-5-(benzothiazolylthiomethyl)benzylidenecyanoacetamide (AG825), and 4-(3-chloroanilino)-6,7-dimethoxyquinazoline (AG1478) from Calbiochem (San Diego, CA); genistein, L- $\alpha$-lysophosphatidic acid, oleoyl (LPA), and phorbol 12,13-dibutyrate (PDBu) from Sigma (St. Louis, MO); recombinant human epidermal growth factor (EGF) from Life Technologies. Protein A-Sepharose CL-4B beads were purchased from Amersham Pharmacia Biotech. Rabbit affinity-purified antibodies to phosphospecific (Thr ${ }^{202} /$ Tyr $^{204}$ ) p44/p42 MAP kinases (ERK1/2) were purchased from New England Biolabs (Beverly, MA). Anti-rat mGluR5 and EGF receptor polyclonal antibodies and monoclonal antiphosphotyrosine antibody (4G10) were purchased from Upstate Biotechnology (Lake Placid, NY). Guinea pig anti-glutamate transporter GLT-1 polyclonal antibody was purchased from Chemicon. Anti-rat EGF receptor polyclonal antibody and anti-mouse phospho-specific $\left(\mathrm{Tyr}^{1173}\right) \mathrm{EGF}$ receptor monoclonal antibody were purchased from Calbiochem. Fluo-3 AM fluorescent calcium indicator was purchased from Molecular Probes (Eugene, OR). Myo- $\left[{ }^{3} \mathrm{H}\right]$-inositol was purchased from American Radiolabeled Chemicals (St. Louis, MO). Medium and supplements were purchased from Life Technologies. Membrane preparations used in positive controls for mGluR5 immunoblots were prepared from human embryonic kidney cells stably transfected to express mGluR5 by Dr. Carmelo Romano (Washington University, St. Louis, MO). The synthesis of the membrane-permeable peptides, MPS-PLC $\beta 1$ and MPS-PLC $\beta 2$, is described in a previous report (Chang et al., 2000).

Statistical analysis. Experimental data were analyzed by one-way ANOVA for multiple comparisons, followed by post-testing with Dunnett's or Newman-Keuls tests of critical difference for comparisons of each condition with controls, as appropriate. Where appropriate, the Student's $t$ test was used to evaluate differences between means. A $p$ value $<0.05$ was considered significant.

\section{RESULTS}

\section{mGluR5 induces ERK2 phosphorylation in cultured rat cortical astrocytes}

A series of studies was performed to test the hypothesis that DHPG-induced increases in ERK2 phosphorylation are mediated by mGluR5. First, cultured rat cortical astrocytes were incubated with the mGluR5 subtype-selective agonist CHPG (Doherty et al., 1997), and ERK2 phosphorylation was measured with a phospho-specific antibody to detect the dually phosphorylated (threonine and tyrosine) form of ERK1/2; then total ERK2 protein was measured by using an antibody to detect ERK1/2. CHPG (2 mM, $10 \mathrm{~min}$ ) caused a significant increase in ERK2 phosphorylation in cultured rat cortical astrocytes comparable with that induced by DHPG (100 $\mu$ m; Fig. $1 A)$. Consistent with our previous report, the treatment of astrocytes with CHPG or DHPG induced no change in total ERK2 protein (Peavy and Conn, 1998). When we treated cortical astrocytes with the noncompetitive mGluR5-selective antagonist MPEP (10 $\mu \mathrm{M}, 10 \mathrm{~min}$; Gasparini et al., 1999), the ERK2 phosphorylation induced by DHPG (12 $\mu \mathrm{M}, 10 \mathrm{~min})$ was inhibited to basal levels. In contrast, treatment with the noncompetitive mGluR1-selective antagonist CPCCOEt (100 $\mu \mathrm{M}, 10 \mathrm{~min}$; Litschig et al., 1999) did not inhibit the DHPG-induced ERK2 phosphorylation (Fig. 1B). Immunoblots prepared with ERK1/2 antibody showed again that changes in ERK2 phosphorylation were not attributable to changes in the levels of total ERK2 protein (Fig. 1B). Together with our previous report that mGluR5 is expressed selectively in these cells, these data suggest that the DHPG-induced increase in ERK2 phosphorylation in cultured rat cortical astrocytes is mediated by mGluR5.

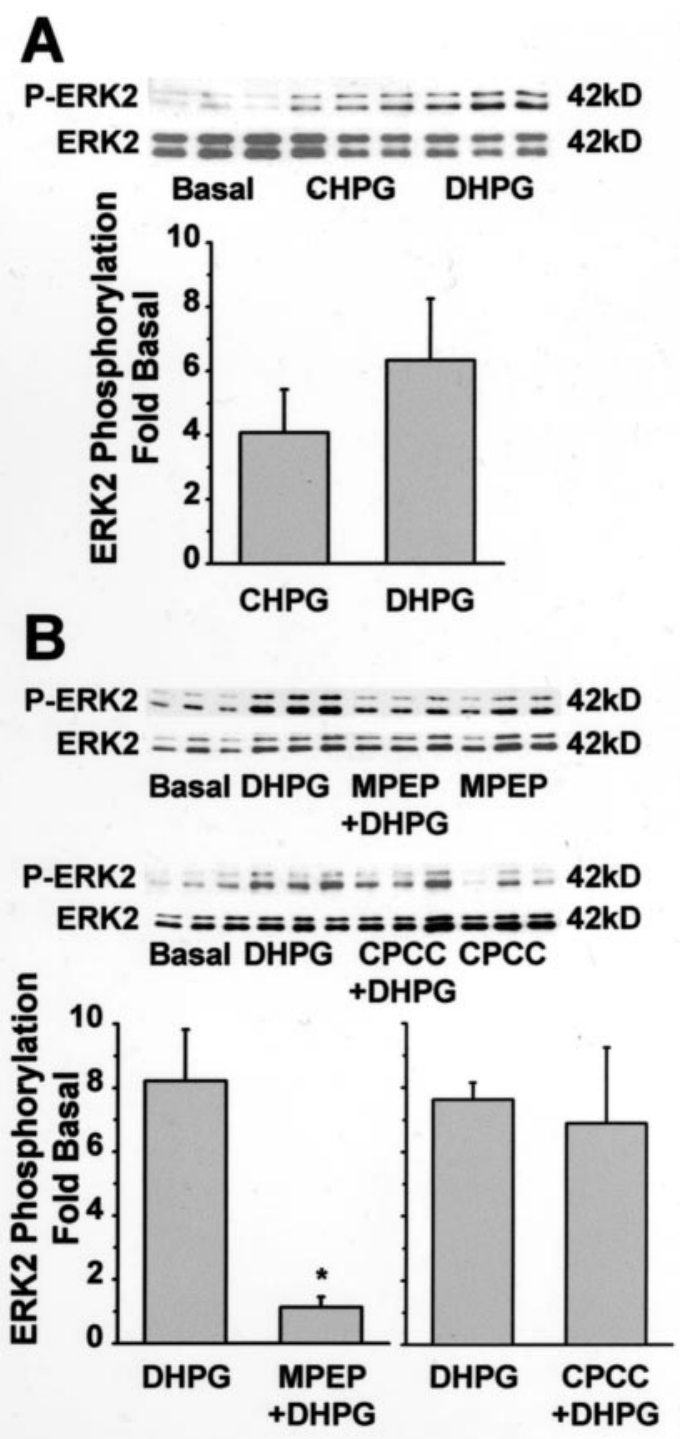

Figure 1. mGluR5-mediated ERK2 phosphorylation in cultured cortical astrocytes. $A$, Treatment of rat astrocytes with CHPG (2 mm, $10 \mathrm{~min}$ ) caused increased phosphorylation of ERK2 no different from that of the effect of DHPG $(100 \mu \mathrm{M}, 10 \mathrm{~min})$, with no change in the total ERK2 protein. Samples were prepared and measured as described in Materials and Methods. Representative immunoblots with a phospho-specific antibody that recognizes the dually phosphorylated form of ERK1/2 (Thr ${ }^{202}$, $\mathrm{Tyr}^{204}$ ) and with an antibody that recognizes total ERK1/2 are shown above the summarized data analyzed from three separate experiments performed in triplicate (mean \pm SEM, $n=3$ ). $B$, Previous treatment of rat astrocytes with the mGluR5-selective antagonist MPEP $(10 \mu \mathrm{M}, 10$ min) completely inhibited ERK2 phosphorylation induced by DHPG (100 $\mu \mathrm{M}, 10 \mathrm{~min})$, whereas treatment with the mGluR1-selective antagonist CPCCOEt $(100 \mu \mathrm{M}, 10 \mathrm{~min})$ did not. Representative immunoblots are shown above the summarized data (mean \pm SEM, $n=3$ or 4 ; ${ }^{*} p<0.05$ ).

\section{mGluR5-induced phosphorylation of ERK2 is dependent on $G_{\alpha q}$, but not on PLC $\beta 1$}

Activation of ERK1 and ERK2 by a variety of G-protein-coupled receptors can be mediated by a number of signaling pathways that are dependent on the activation of either $G_{\alpha}$ or $G_{\beta \gamma}$ subunits of the heterotrimeric G-proteins (Della Rocca et al., 1997). However, previous studies suggest that group I mGluRs also can activate tyrosine kinase signaling cascades by a mechanism that is independent of G-protein activation (Heuss et al., 1999). To 
determine whether the mGluR5-induced phosphorylation of ERK2 is dependent on $G_{\alpha}$ or $G_{\beta \gamma}$ subunits, we used a strategy of targeted disruption of protein-protein interactions involved in G-protein signaling. Membrane-permeable inhibitors, composed of a membrane-permeable sequence conjugated to a peptide sequence targeted to interaction domains of the G-protein subunits, were used to interfere with specific steps in the signaling cascade. These peptides were used in a previous study to dissect the signaling pathways of 5-HT2C receptors (Chang et al., 2000). Treatment of cultured cortical astrocytes with the peptide MPSPLC $\beta 1$ (100 $\mu \mathrm{M}, 30 \mathrm{~min}$ ), which is based on the PLC $\beta 1$ sequence that interacts with activated $G_{\alpha q}$, inhibited ERK2 phosphorylation induced by a subsequent 10 min application of DHPG (100 $\mu \mathrm{M}$; Fig. 2A). Consistent with the inhibition of $\mathrm{G}_{\alpha q}$, treatment with MPS-PLC $\beta 1(100 \mu \mathrm{M}, 30 \mathrm{~min})$ also inhibited DHPGinduced phosphoinositide (PI) hydrolysis in cultured cortical astrocytes (Fig. $2 A$ ). In contrast, MPS-PLC $\beta 1$ did not inhibit LPAinduced $(10 \mu \mathrm{M}, 15 \mathrm{~min})$ phosphorylation of ERK2 in cultured astrocytes (Fig. 2A). LPA has been shown to activate MAP kinase signaling in astrocytic cells (Pebay et al., 1999) and in COS-7 cells (Luttrell et al., 1996) by a pertussis toxin-sensitive, $\mathrm{G}_{\beta \gamma}$-dependent mechanism. Thus, MPS-PLC $\beta 1$ is likely to inhibit the response to mGluR5 activation by disrupting $\mathrm{G}_{\alpha \mathrm{q}}$ signaling.

In contrast to MPS-PLC $\beta 1$, treatment of cultured cortical astrocytes with MPS-PLC $\beta 2$ peptide $(10 \mu \mathrm{M}, 30 \mathrm{~min})$ had no effect on DHPG-induced (100 $\mu \mathrm{M}, 10 \mathrm{~min})$ or EGF-induced $(10 \mathrm{ng} / \mathrm{ml}$, $10 \mathrm{~min}$ ) ERK2 phosphorylation (Fig. $2 \mathrm{~B}$ ). MPS-PLC $\beta 2$ peptide is based on the PLC $\beta 2$ sequence that interacts with free $\mathrm{G}_{\beta \gamma}$. Consistent with an ability to block $\mathrm{G}_{\beta \gamma}$-mediated signaling, MPSPLC $\beta 2$ inhibited LPA-induced phosphorylation of ERK2 (Fig. $2 B$ ). Furthermore, treatment of cultured cortical astrocytes overnight with pertussis toxin $(100 \mathrm{ng} / \mathrm{ml})$ did not inhibit the DHPGinduced ERK2 phosphorylation, suggesting a lack of involvement of $\mathrm{G}$-proteins of the $\mathrm{G}_{\mathrm{i} / \mathrm{o}}$ family in this signal cascade (data not shown). Together, these results suggest that mGluR5-mediated ERK2 activation is dependent on the activation of $\mathrm{G}_{\alpha \mathrm{q}}$ and is not mediated by $\mathrm{G}_{\beta \gamma}$ subunits.

The predominant effector protein activated by $\mathrm{G}_{\alpha q}$ is PLC $\beta 1$. Thus, the finding that the DHPG-induced increase in ERK2 phosphorylation is dependent on $\mathrm{G}_{\alpha \mathrm{q}}$ activation raises the possibility that this response is mediated by the activation of PLC $\beta 1$ and the hydrolysis of phosphoinositides. Consistent with this idea, both of the major PLC $\beta 1$-derived second messenger systems (i.e., inositol trisphosphate/calcium and diacylglycerol/protein kinase C) can increase ERK2 phosphorylation in other systems (Della Rocca et al., 1997). We have reported previously that the inhibition of protein kinase $\mathrm{C}$ had no effect on DHPG-induced ERK2 phosphorylation, suggesting that this response is not mediated by the activation of PKC (Peavy and Conn, 1998). To test the involvement of PLC $\beta 1$, we used U73122, an amino steroid inhibitor of this enzyme. Consistent with the ability to inhibit PLC $\beta 1$, U73122 (10 $\mu \mathrm{M}, 30 \mathrm{~min})$ completely blocked DHPGinduced (100 $\mu \mathrm{M}, 10 \mathrm{~min})$ increases in PI hydrolysis (Fig. $3 A$ ). In contrast, U73122 failed to inhibit the DHPG-induced (100 $\mu \mathrm{M}, 10$ min) increases in ERK2 phosphorylation (Fig. 3A). Furthermore, to test the involvement of increases in intracellular calcium, we used the cell-permeable calcium chelator BAPTA-AM. BAPTA-AM completely inhibited the DHPG-induced increase in intracellular calcium concentration as measured by calcium fluo-3 fluorescence (Fig. 3B). However, a concentration of BAPTA-AM $(30 \mu \mathrm{M}, 30 \mathrm{~min})$ that was maximally effective in inhibiting the calcium response in these cells failed to inhibit

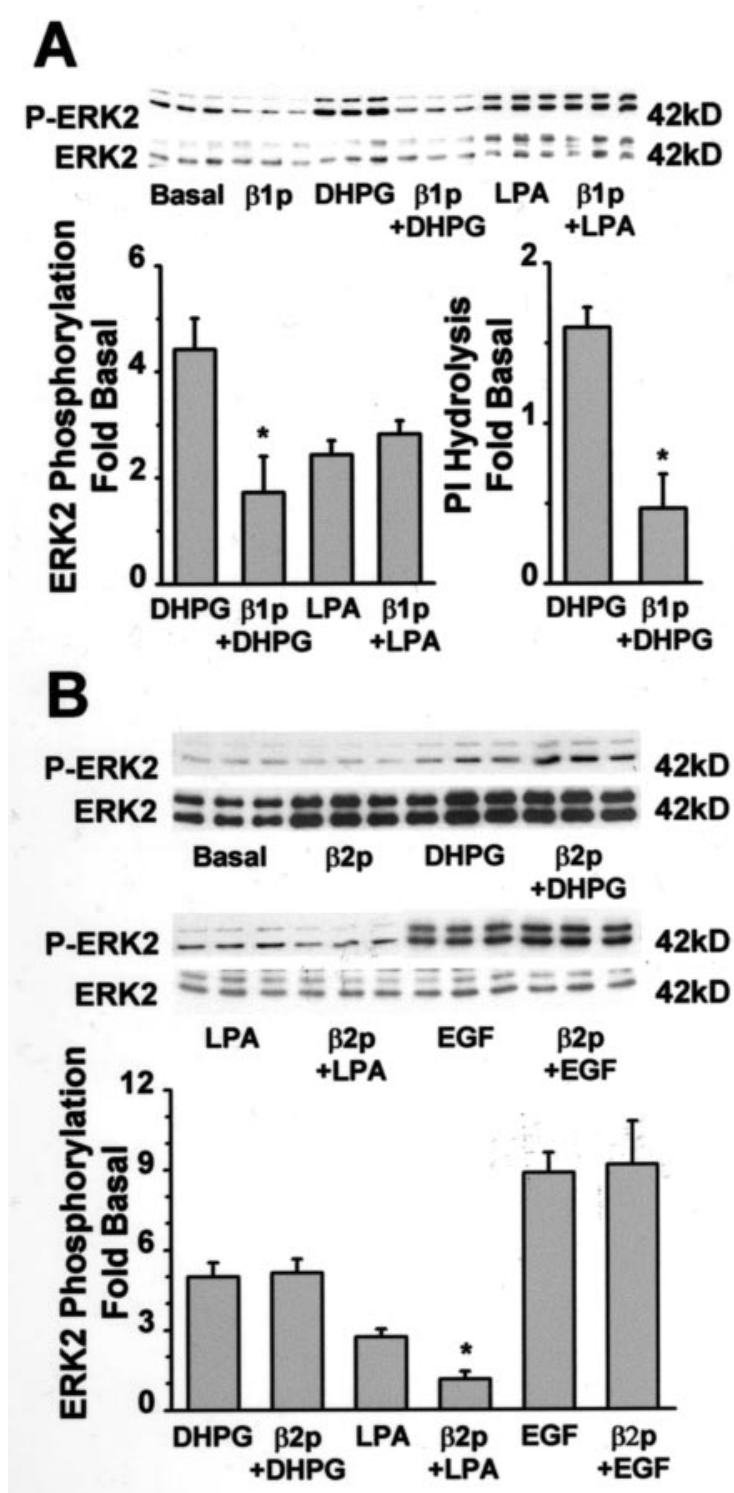

Figure 2. G-protein dependence of mGluR5-mediated ERK2 phosphorylation. $A$, Previous treatment of rat astrocytes with the $\mathrm{G}_{\alpha q}$-targeted peptide MPS-PLC $\beta 1(100 \mu \mathrm{M}, 30 \mathrm{~min})$ inhibited DHPG-induced (100 $\mu \mathrm{M}, 10 \mathrm{~min}$ ) ERK2 phosphorylation and phosphoinositide hydrolysis. In contrast, LPA-induced (10 $\mu \mathrm{M}, 15 \mathrm{~min})$ ERK2 phosphorylation was not inhibited by MPS-PLC $\beta 1$ treatment. Representative immunoblots are shown above the summarized data (mean $\pm \mathrm{SEM}, n=5$ or 6 ; ${ }^{*} p<0.05$ ). $B$, Previous treatment with the $\mathrm{G}_{\beta \gamma}$-targeted peptide MPS-PLC $\beta 2(10 \mu \mathrm{M}$, 30 min) did not inhibit DHPG- or EGF-induced ERK2 phosphorylation but did inhibit the effect of LPA (10 $\mu \mathrm{M}, 10 \mathrm{~min})$. Representative immunoblots are shown above the summarized data (mean \pm SEM, $n=6,7$, or $11 ; * p<0.05)$.

DHPG-induced (100 $\mu \mathrm{M}, 10 \mathrm{~min})$ ERK2 phosphorylation (Fig. $3 B)$. Together, these results provide strong evidence that mGluR5-mediated increases in ERK2 phosphorylation are not dependent on the activation of PLC $\beta 1$ and downstream second messengers that are generated by PLC $\beta 1$ activity.

mGluR5-mediated ERK2 phosphorylation is dependent on a Src family tyrosine kinase

Given evidence for the absence of PLC $\beta 1$ involvement in the mGluR5-mediated ERK2 phosphorylation, we investigated the 


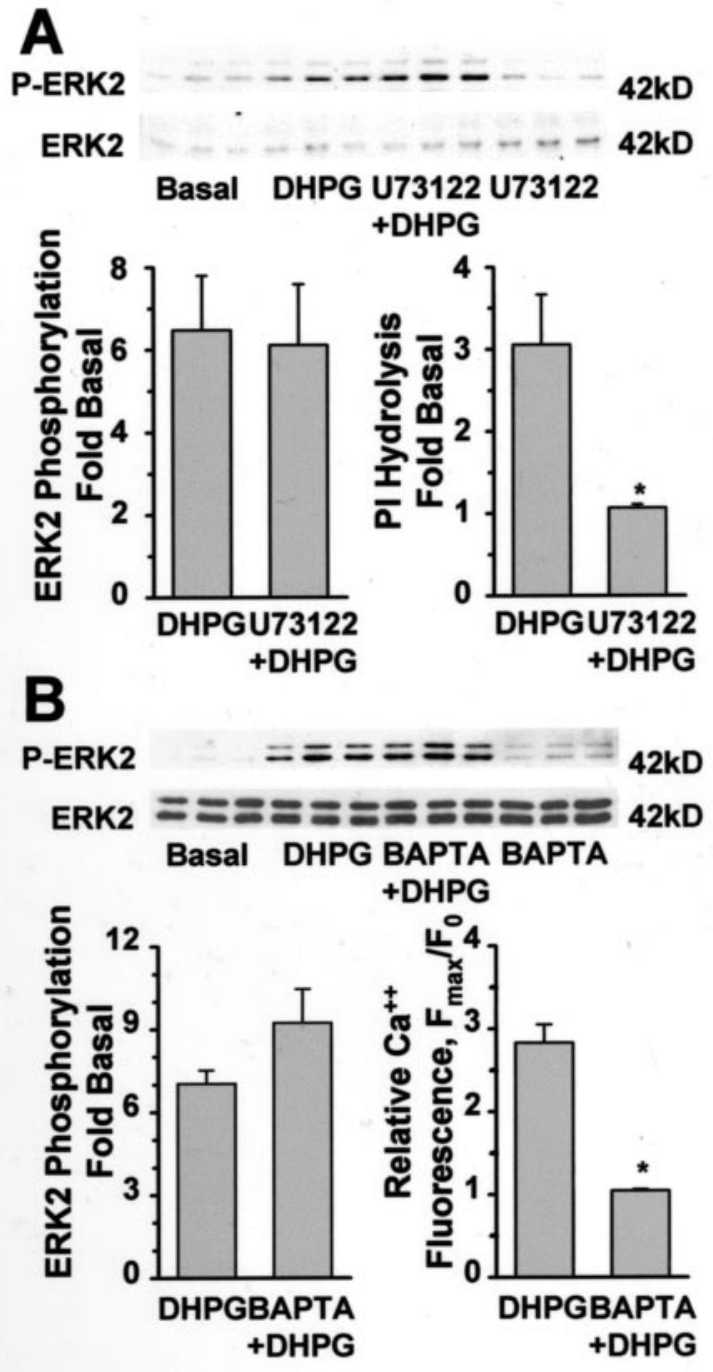

Figure 3. PLC $\beta 1$ inhibition does not block mGluR5-mediated ERK2 phosphorylation. $A$, Treatment with the PLC $\beta 1$ inhibitor U73122 $(10 \mu \mathrm{M}$, $30 \mathrm{~min}$ ) completely blocked DHPG-induced (100 $\mu \mathrm{M}, 10 \mathrm{~min})$ phosphoinositide hydrolysis but did not inhibit ERK2 phosphorylation in rat astrocytes. Representative immunoblots are shown above the summarized data (mean \pm SEM, $n=4$ or $5 ;{ }^{*} p<0.05$ ). $B$, Previous incubation with the calcium chelator BAPTA-AM (30 $\mu \mathrm{M}, 30 \mathrm{~min})$ completely inhibited increases in intracellular calcium from the application of DHPG $(100 \mu \mathrm{M}, 30 \mathrm{sec})$ to rat astrocytes but did not inhibit DHPG-induced (100 $\mu \mathrm{M}, 10 \mathrm{~min})$ ERK2 phosphorylation. Representative immunoblots are shown above the summarized data (mean $\pm \operatorname{SEM}, n=3$ or $12 ;{ }^{*} p<0.05$ ).

possible role of tyrosine kinases, which often have been demonstrated as necessary for ERK activation. We noted that mGluR5 stimulation in cultured astrocytes resulted in tyrosine phosphorylation of several proteins in addition to ERK2 (Peavy and Conn, 1998). It has been reported that tyrosine kinases can serve as effectors for $\mathrm{G}_{\alpha \mathrm{q}}$ (Bence et al., 1997; Ma and Huang, 1998), and some models of G-protein-coupled receptor activation of ERKs require recruitment of Src family tyrosine kinases (Daub et al., 1997; Della Rocca et al., 1997; Luttrell et al., 1996, 1997). We therefore used genistein (Akiyama and Ogawara, 1991), a general tyrosine kinase inhibitor, to determine whether activation of tyrosine kinases was required for DHPG-induced ERK2 phosphorylation. Genistein (100 $\mu \mathrm{M}, 30 \mathrm{~min})$ inhibited ERK2 phosphorylation that was induced by the application of DHPG (100

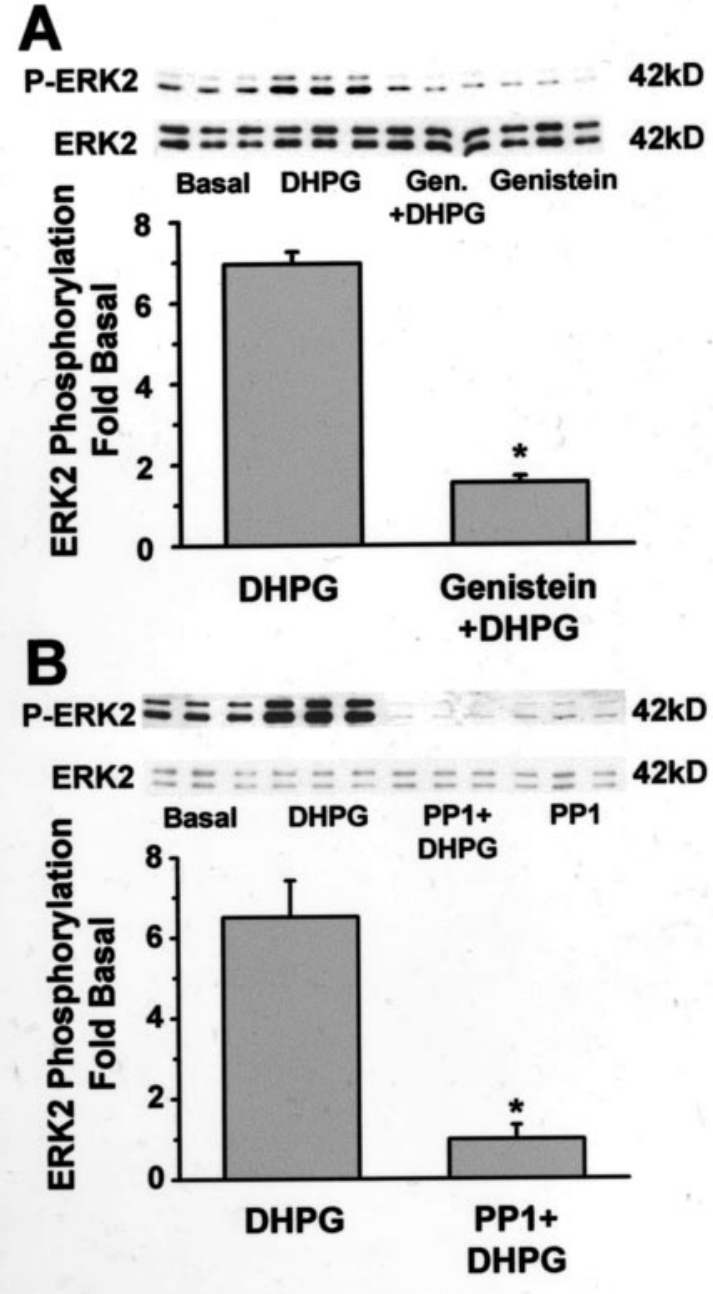

Figure 4. Src dependence of mGluR5-mediated ERK2 phosphorylation. $A$, Treatment with the tyrosine kinase inhibitor genistein $(100 \mu \mathrm{M}, 30$ min) inhibited DHPG-induced (100 $\mu \mathrm{M}, 10 \mathrm{~min})$ ERK2 phosphorylation in rat astrocytes. Representative immunoblots are shown above the summarized data (mean \pm SEM, $n=3$; $p<<0.05$ ). $B$, The Src family inhibitor PP1 (5 $\mu \mathrm{M}, 30 \mathrm{~min}$ ) also completely inhibited DHPG-induced $(100 \mu \mathrm{M}, 10 \mathrm{~min})$ phosphorylation of ERK2 in rat astrocytes. Representative immunoblots are shown above the summarized data (mean \pm SEM, $n=3 ; * p<0.05)$.

$\mu \mathrm{M}, 10 \mathrm{~min}$; Fig. 4A). A more selective inhibitor of the Src family of tyrosine kinases, PP1 (5 $\mu \mathrm{M}, 30$ min; Hanke et al., 1996), also substantially decreased both basal and DHPG-induced ERK2 phosphorylation (Fig. 4B). Accounting for the reduction in basal levels of ERK2 phosphorylation when treated with PP1 alone, we found that PP1 completely blocked the DHPG-induced phosphorylation of ERK2. These data suggest that Src activity both contributes to basal ERK2 phosphorylation and is required for mGluR5-mediated ERK2 phosphorylation. Consistent with other reports of activation of ERK1/2 by G-protein-coupled receptors, these data implicated a Src family tyrosine kinase in the mGluR5mediated phosphorylation of ERK2 but in a manner independent of G $\beta \gamma$, PLC $\beta 1$, PKC, or increased intracellular calcium.

\section{EGF receptor activation is required for mGluR5- mediated ERK2 phosphorylation}

In the recent years receptor tyrosine kinases, such as the EGF receptor or platelet-derived growth factor receptor, have been 


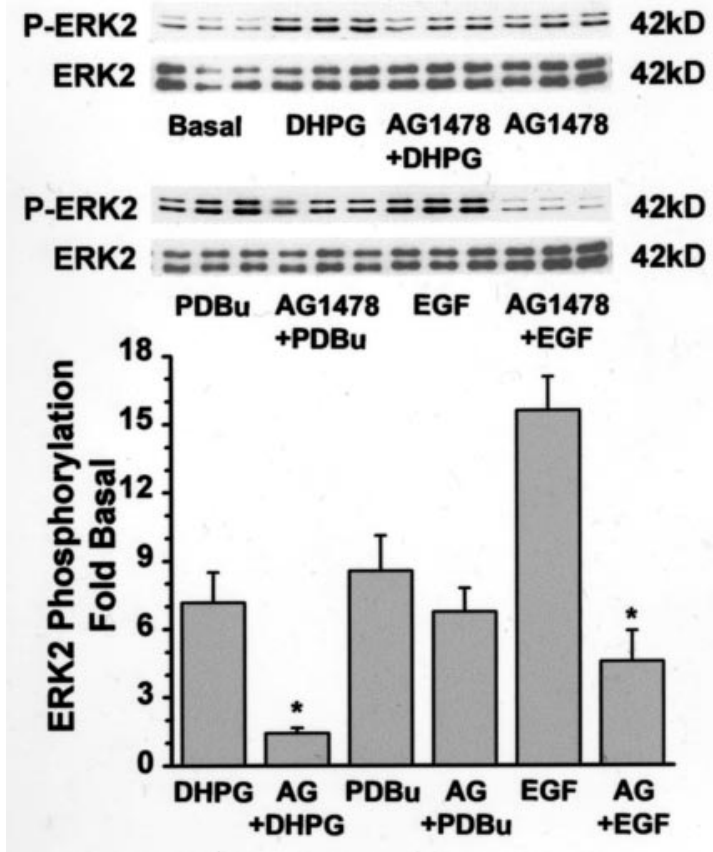

Figure 5. EGF receptor inhibition blocks mGluR5-mediated ERK2 phosphorylation. Previous treatment of rat astrocytes with the EGF receptor inhibitor AG1478 (100 nM, $10 \mathrm{~min}$ ) blocked DHPG-induced (100 $\mu \mathrm{M}, 10 \mathrm{~min})$ as well as EGF-induced $(10 \mathrm{ng} / \mathrm{ml}, 10 \mathrm{~min})$ ERK2 phosphorylation. In contrast, ERK2 phosphorylation induced by PDBu $(1 \mu \mathrm{M}, 10$ min) was not inhibited by AG1478. Representative immunoblots are shown above the summarized data (mean \pm SEM, $n=3$ or 4 ; ${ }^{*} p<0.05$ ).

implicated in signaling from G-protein-coupled receptors to ERK1/2 (Daub et al., 1997; Luttrell et al., 1999a; Leserer et al., 2000). Thus, we tested the hypothesis that mGluR5-mediated transactivation of a receptor tyrosine kinase might be responsible for the DHPG-induced phosphorylation of ERK2. The tyrphostin, AG1478, is a selective inhibitor of the EGF receptor (ErbB1; Levitzki and Gazit, 1995). Interestingly, AG1478 (100 nM, 10 min) markedly inhibited DHPG-induced (100 $\mu \mathrm{M}, 10 \mathrm{~min})$ increases in ERK2 phosphorylation (Fig. 5). Consistent with its ability to inhibit the EGF receptor, AG1478 also inhibited EGFinduced (10 ng/ml, $10 \mathrm{~min})$ ERK2 phosphorylation. However, AG1478 did not inhibit increases in ERK2 phosphorylation in response to the $\mathrm{PKC}$ activator $\mathrm{PDBu}(1 \mu \mathrm{M}, 10 \mathrm{~min})$. AG825, a related tyrphostin that selectivity inhibits the related receptor tyrosine kinase ErbB2 with no effects on ErbB1 (Osherov et al., 1993), had no effect on the DHPG-induced (100 $\mu \mathrm{M}, 10 \mathrm{~min})$ phosphorylation of ERK2 when applied at a higher concentration (5 $\mu \mathrm{M}, 10 \mathrm{~min}$ ).

With activation, receptor tyrosine kinases dimerize and autophosphorylate at specific tyrosine residues (Leserer et al., 2000). As an additional measure of EGF receptor activation, we measured the tyrosine phosphorylation by immunoprecipitation of the native EGF receptors from astrocytic cell lysates, followed by immunoblotting with an anti-phosphotyrosine antibody. DHPG $(100 \mu \mathrm{M})$ induced an increase in the tyrosine phosphorylation of the EGF receptor that could be inhibited by previous treatment with AG1478 (100 nM, 10 min; Fig. 6). Immunoblotting with the EGF receptor antibody showed that mGluR5 stimulation did not alter the overall expression of the EGF receptor. Similar results were obtained when astrocytes were treated with DHPG $(100 \mu \mathrm{M}$, $10 \mathrm{~min})$, and we measured EGF receptor phosphorylation by

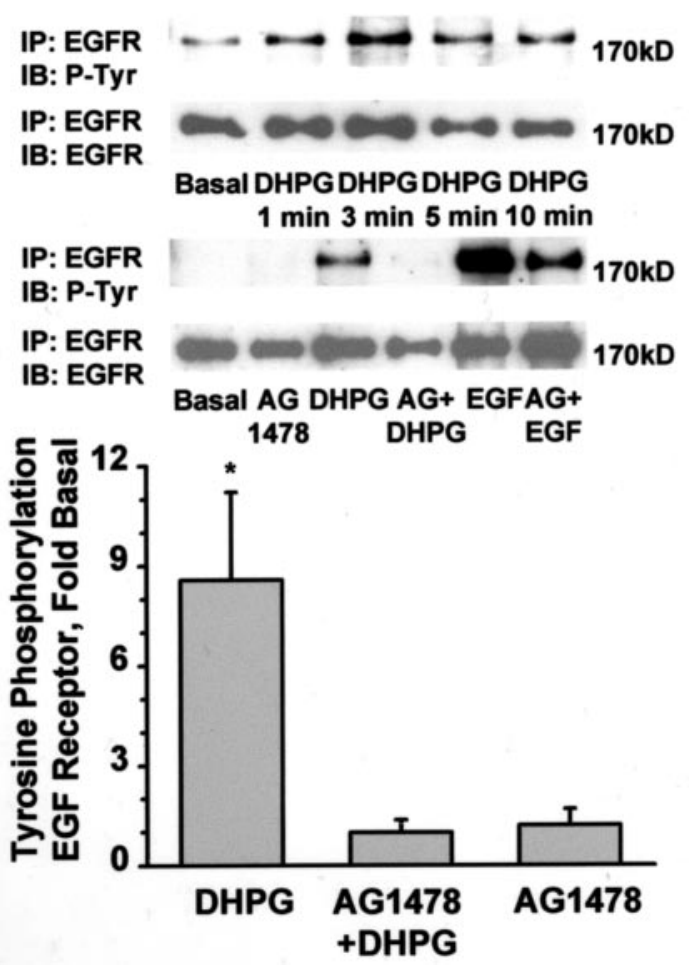

Figure 6. mGluR5-mediated EGF receptor phosphorylation. Treatment of rat astrocytes with DHPG $(100 \mu \mathrm{M})$ caused increases in tyrosine phosphorylation of the EGF receptor but no change in total EGF receptor expression. The DHPG- and EGF-induced increases in EGF receptor tyrosine phosphorylation were blocked by previous treatment with the EGF receptor inhibitor AG1478. Samples were prepared and measured as described in Materials and Methods. After immunoprecipitation of the EGF receptor with a selective antibody, the immunoblots were prepared with a phosphotyrosine antibody. Representative immunoblots are shown above the summarized and analyzed data from five separate experiments $\left(\right.$ mean \pm SEM, $n=5 ;{ }^{*} p<0.05$ ).

using a phospho-specific antibody that recognizes the major autophosphorylation site $\left(\mathrm{Tyr}^{1173}\right)$ of the EGF receptor (Fig. 7). Together, these results provide strong evidence for mGluR5mediated transactivation of the EGF receptor and subsequent phosphorylation of ERK2. Because our ERK2 experiments with the $\mathrm{G}_{\alpha \mathrm{q}}$-targeted peptide MPS-PLC $\beta 1$ (Fig. $2 A$ ) suggested a role for $\mathrm{G}_{\alpha \mathrm{q}}$ in the DHPG-induced phosphorylation of ERK2, we also measured DHPG-induced phosphorylation of the EGF receptor in the presence and absence of MPS-PLC $\beta 1$ to test the hypothesis that mGluR5 mediates transactivation of the EGF receptor via $\mathrm{G}_{\alpha \mathrm{q}}$. Previous treatment with MPS-PLC $\beta 1(100 \mu \mathrm{M}, 30 \mathrm{~min})$ blocked the DHPG-induced increase in EGF receptor phosphorylation (Fig. 7). These results suggest that mGluR5-mediated transactivation of the EGF receptor is dependent on active $G_{\alpha q}$ and are consistent with those seen in DHPG-induced ERK2 phosphorylation, which was inhibited by MPS-PLC $\beta 1$ (Fig. 2A).

Models for GPCR transactivation of receptor tyrosine kinases include Src-dependent and Src-independent mechanisms (Daub et al., 1997; Maudsley et al., 2000). To examine the role of Src tyrosine kinases in the mGluR5-mediated transactivation of the EGF receptor, we treated astrocytes with the selective Src inhibitor PP1 (5 $\mu \mathrm{M}, 30 \mathrm{~min})$. PP1 had no effect on the DHPG-induced $(100 \mu \mathrm{M}, 5 \mathrm{~min})$ tyrosine phosphorylation of the EGF receptor (Fig. $8 A$ ). Furthermore, the PLC $\beta 1$ inhibitor U73122 (10 $\mu \mathrm{M}, 30$ min) also had no effect on DHPG-induced (100 $\mu \mathrm{M}, 3 \mathrm{~min})$ 


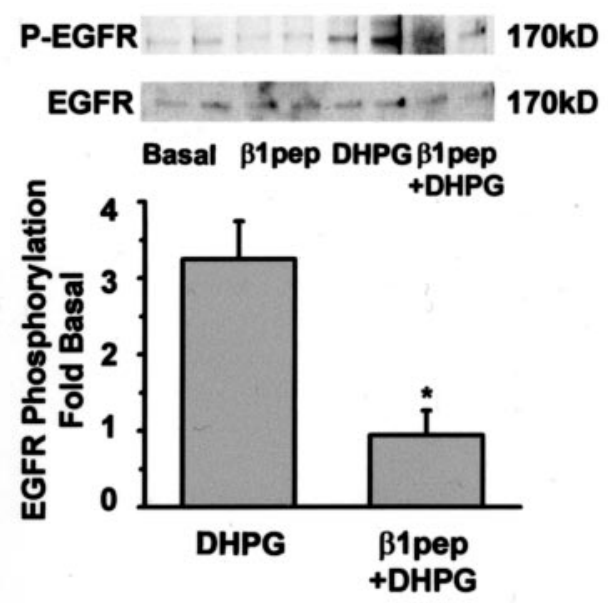

Figure 7. mGluR5-mediated phosphorylation of the EGF receptor is dependent on active $G_{\alpha q}$. Previous treatment of rat astrocytes with the $\mathrm{G}_{\alpha \mathrm{q}}$-targeted peptide MPS-PLC $\beta 1(100 \mu \mathrm{M}, 30 \mathrm{~min})$ inhibited DHPGinduced $(100 \mu \mathrm{M}, 10 \mathrm{~min})$ EGF receptor phosphorylation. Expression of the EGF receptor was not altered by treatments. Samples were prepared and measured as described in Materials and Methods. Representative immunoblots with a phospho-specific antibody that recognizes the major autophosphorylation site of the EGF receptor $\left(\mathrm{Tyr}^{1173}\right)$ and with an antibody that recognizes total EGF receptor are shown above the summarized data analyzed from duplicate samples from three separate experiments (mean \pm SEM, $n=3 ; * p<0.05$ ).
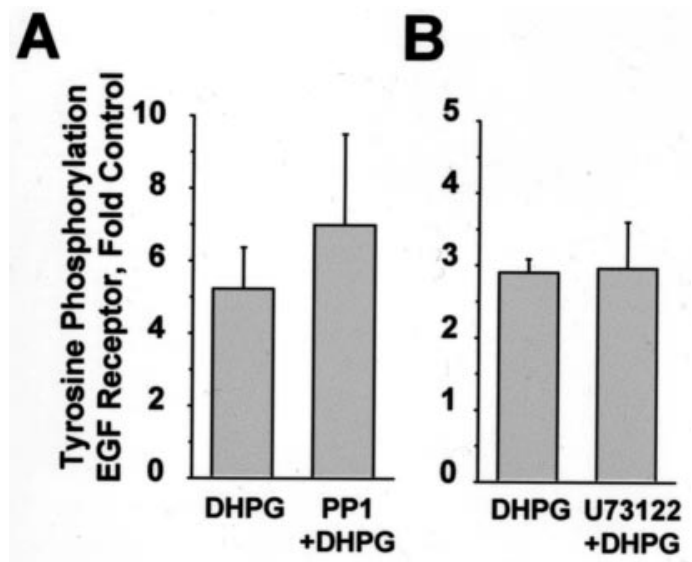

Figure 8. mGluR5-mediated transactivation of the EGF receptor is not Src-dependent. $A$, The Src family-selective inhibitor PP1 (5 $\mu \mathrm{M}, 30 \mathrm{~min})$ did not inhibit DHPG-induced $(100 \mu \mathrm{M}, 5 \mathrm{~min})$ phosphorylation of tyrosine residues on the EGF receptor (mean \pm SEM, $n=4 ; p<0.05$ ). $B$, The PLC $\beta 1$ inhibitor U73122 $(10 \mu \mathrm{M}, 30 \mathrm{~min})$ also did not inhibit DHPG-induced (100 $\mu \mathrm{M}, 3 \mathrm{~min})$ tyrosine phosphorylation of the EGF receptor (mean \pm SEM, $n=3 ; p<0.05$ ).

tyrosine phosphorylation of the EGF receptor, as expected from our results measuring mGluR5-mediated ERK2 phosphorylation (Fig. 8B). These results suggest that mGluR5-mediated phosphorylation of ERK2 is dependent on activation of the EGF receptor, followed by the downstream activation of Src and the phosphorylation of ERK2.

\section{DHPG induces mGluR5 and EGF receptor association}

A recent report (Maudsley et al., 2000) suggested a model for the $\beta_{2}$-adrenergic receptor activation of ERK1/2 via an agonistdependent formation of a multiprotein complex of Src, the EGF receptor, and the $\beta_{2}$-adrenergic receptor. With this model in

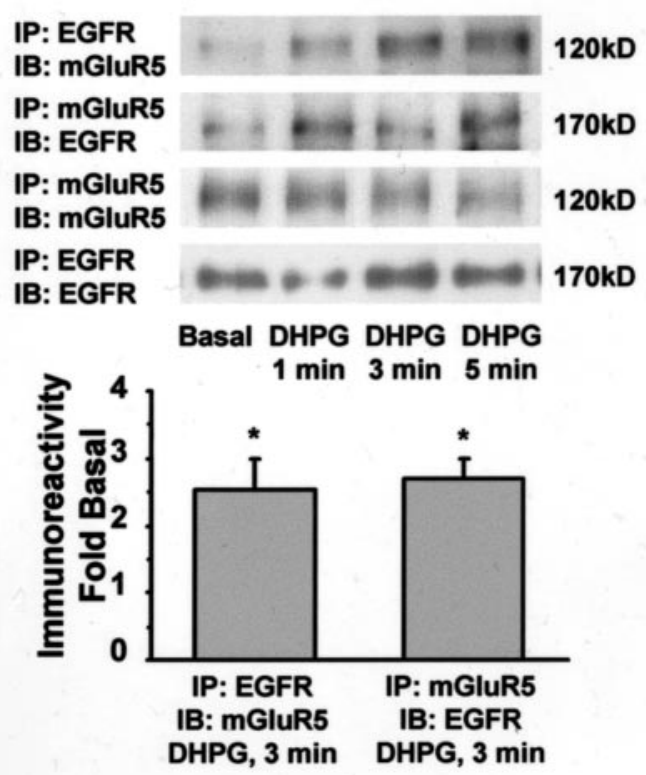

Figure 9. mGluR5 and EGF receptors coimmunoprecipitate. Treatment of rat astrocytes with DHPG $(100 \mu \mathrm{M})$ caused an increase in the association of the EGF receptor with mGluR5. Samples were prepared and measured as indicated in Materials and Methods. After immunoprecipitation of the EGF receptor with a selective antibody, the immunoblots were prepared by using an antibody for mGluR5. Also, immunoprecipitates with the mGluR5 antibody were used to prepare immunoblots probed with the EGF receptor antibody. Representative immunoblots from 10 separate experiments ( 4 with mGluR5 and 6 with EGF receptor immunoprecipitation) are shown at the top. Controls immunoblots with the immunoprecipitating antibody are shown also. Summarized data for mGluR-EGF receptor coimmunoprecipitation at $3 \mathrm{~min}$ are shown at the bottom (mean \pm SEM, $n=4$ or 6 ; $* p<0.05$ ).

mind, we used a coimmunoprecipitation protocol to examine the physical association of mGluR5 and the EGF receptor in cultured cortical astrocytes. DHPG $(100 \mu \mathrm{M})$ induced an increase in the amount of mGluR5 detected in EGF receptor immunoprecipitates and the amount of EGF receptor detected in mGluR5 immunoprecipitates (Fig. 9). In contrast, the glutamate transporter GLT-1, which also is expressed in cortical astrocytes (Gegelashvili et al., 2000), did not coimmunoprecipitate with either the EGF receptor or mGluR5 when treated with DHPG (data not shown). These results are consistent with the model for multiprotein complexes containing G-protein-coupled receptors and receptor tyrosine kinases signaling to ERK1/2 activation.

\section{DISCUSSION}

The data that were presented suggest that mGluR5 couples to the activation of ERK2 in cortical astrocytes by a novel signaling pathway. We found that mGluR5-mediated phosphorylation of ERK2 is dependent on the activation of $G_{\alpha q}$ and transactivation of the EGF receptor but is independent of PLC $\beta 1$. Furthermore, our results suggest that a Src family tyrosine kinase is required for ERK2 phosphorylation, but Src is activated downstream from the activation of the EGF receptor. Finally, coimmunoprecipitation studies reveal an association of the mGluR5 and the EGF receptor. This represents a novel signaling mechanism for group I mGluRs and a novel mechanism for GPCR activation of MAP kinases that is primarily consistent with many previously described models, yet with some distinct differences. 


\section{Signaling from mGluR5 to ERK2 in cultured rat cortical astrocytes}

Our conclusion that mGluR5 induces activation of ERK2 via transactivation of the EGF receptor is supported by two commonly used measures of receptor tyrosine kinase transactivation: tyrosine phosphorylation of the EGF receptor and the inhibition of the phosphorylation of downstream substrates (i.e., ERK2) by the tyrphostin AG1478. Activation of the EGF receptor occurs when the binding of extracellular ligands or transactivation by GPCRs causes dimerization of the EGF receptors and autophosphorylation of specific tyrosine residues. Activation of the EGF receptor by autophosphorylation leads to a rapid increase in the tyrosine phosphorylation of adaptor proteins such as Shc and Gab1, the assembly of Shc-Grb2-SoS complexes, and the subsequent activation of the Ras-Raf mitogenic pathway, which leads to activation of the MAP kinases such as ERK1/2. Stimulation of endogenous mGluR5 in astrocytes by DHPG caused an increase in the tyrosine phosphorylation of the EGF receptor. DHPGinduced phosphorylation of the EGF receptor was evident at the earliest time point measured (1 min) and was consistent with the time course of ERK2 phosphorylation reported in our previous study (Peavy and Conn, 1998). DHPG-induced tyrosine phosphorylation of the EGF receptor was blocked by the tyrphostin AG1478, which is selective for the inhibition of EGF receptor signaling. AG1478 also inhibited DHPG-induced phosphorylation of ERK2. Similar results have been reported for a variety of $\mathrm{G}_{\mathrm{i} / \mathrm{o}^{-}}$and $\mathrm{G}_{\mathrm{q}}$-coupled receptors, including thrombin, angiotensin II, bradykinin, endothelin, purinergic, and LPA (Daub et al., 1997; Soltoff, 1998; Adomeit et al., 1999; Della Rocca et al., 1999; Prenzel et al., 1999; Seo et al., 2000), suggesting that transactivation of receptor tyrosine kinases is a common mechanism for activation of MAP kinase pathways by GPCRs.

It will be of interest to determine whether transactivation of receptor tyrosine kinases by a mechanism that is dependent on $\mathrm{G}_{\alpha \mathrm{q}}$ but independent of PLC $\beta 1$ or $\mathrm{G}_{\beta \gamma}$ is shared by other GPCRs. Consistent with this possibility, neither increases in intracellular calcium nor activation of PKC are required for $\alpha-1 \mathrm{~A}$ adrenergic receptor-mediated activation of MAP kinases in PC12 cells (Berts et al., 1999), although these receptors are known to couple to $\mathrm{G}_{\alpha \mathrm{q}}$. Thrombin and Pasteurella multocida toxin-induced activation of MAP kinases also exhibits similar characteristics in human embryonic kidney (HEK) 293 cells, including dependence on activated $\mathrm{G}_{\alpha \mathrm{q}}$, EGF receptor transactivation, and Ras, but not PKC activation (Seo et al., 2000). Our results with the PLC $\beta 1$ inhibitor U73122 demonstrate that activation of PLC $\beta 1$ is not necessary for mGluR5-mediated ERK2 phosphorylation and are supported by evidence that PKC activation and increases in intracellular calcium downstream from PLC $\beta 1$ also are without effect on this response. Inhibition of the mGluR5-mediated ERK2 phosphorylation by the peptide inhibitor MPS-PLC $\beta 1$, targeted to activated $G_{\alpha q}$ subunits, suggests that the signal pathway may diverge upstream from PLC $\beta 1$ activation and introduces the possibility of coupling of another effector to $G_{\alpha q}$.

Although the details of the mechanism involved in mGluR5mediated activation of MAP kinase signaling are not clear, we must consider the possibility of direct coupling to a tyrosine kinase via $\mathrm{G}_{\alpha \mathrm{q}}$. We have reported previously that mGluR stimulation in astrocytes induced tyrosine phosphorylation of several proteins (Peavy and Conn, 1998). Furthermore, glutamate induces tyrosine phosphorylation of Pyk2 and FAK in rat hippocampal slices and in astrocytes via a pathway that could be inhibited by the tyrosine kinase inhibitor genistein (Siciliano et al., 1994, 1996). There are reports of tyrosine kinases coupling to $\mathrm{G}_{\alpha}$ subunits, including Bruton's tyrosine kinase (Bence et al., 1997; Ma and Huang, 1998) and Src (Ma et al., 2000).

It is important to note that glutamate-stimulated activation of MAP kinase in astrocytes recently was reported to be mediated by a pertussis toxin-sensitive, calcium- and PKC-dependent pathway (Schinkmann et al., 2000). However, our studies used different cell cultures, protocols, and assay systems and used selective agonists to distinguish among glutamate receptors. More importantly, it is possible that the activation of both ionotropic and metabotropic receptors in astrocytes by glutamate could induce a response that is dependent on the activation of pathways that are distinct from those activated by selective group I mGluR agonists. In fact, there is evidence for ionotropic glutamate receptors in association with $\mathrm{G}_{\alpha \mathrm{i}}$ and coupling to MAP kinases via a pertussis toxin-sensitive pathway (Dingledine et al., 1999).

The association of mGluR5 and the EGF receptor suggested by the results of coimmunoprecipitation experiments is consistent with the model for mitogenic signaling complexes proposed in recent reports, with the EGF receptor serving as a scaffold for the assembly of desensitized G-protein-coupled receptors, Src, $\beta$-arrestin, and adaptor proteins as structural components of the complex (Luttrell et al., 1999b; Maudsley et al., 2000). In our study we have not endeavored to determine whether additional components of a signaling complex are present in mGluR5 or EGF receptor immunoprecipitates. However, several reports point to possible GRK and arrestin-mediated mechanisms for mGluR desensitization and internalization consistent with models for a multiprotein signaling complex. In catfish olfactory neurons glutamate stimulates clathrin-dependent internalization of mGluR1 (Rankin et al., 1999), and DHPG induces internalization of mGluR5 in cultured guinea pig enteric neurons (Liu and Kirchgessner, 2000). Coexpression of GRKs with mGluR1a in HEK 293 cells demonstrated that mGluR1a activity may be regulated by GRKs (Dale et al., 2000). In Purkinje neurons GRK4 regulates mGluR1a, mediating receptor desensitization and internalization and GRK redistribution; mGluR1a and GRK4 colocalize and, with agonist stimulation, redistribute to intracellular vesicles (Sallese et al., 2000). GRK2 and GRK3 are expressed in cultured rat astrocytes and appear to regulate receptor signaling when coexpressed with mGluR5 in HEK 293 cells (S. D. Sorensen and P. J. Conn, unpublished observations).

\section{Physiological significance of EGF receptor activation and MAP kinase stimulation in astrocytes}

The potential physiological consequences of mGluR5-mediated ERK2 activation in astrocytes have not been determined fully. As has been exhibited by other G-protein-coupled receptors, the activation of MAP kinases via a pathway common to receptor tyrosine kinases results in increases in cell proliferation and protein synthesis. Consistent with this, glutamate and DHPG increase [methyl- ${ }^{3} \mathrm{H}$ ] thymidine incorporation in cultured astrocytes, indicative of increased cell proliferation (Ciccarelli et al., 1997; Schinkmann et al., 2000). In astrocytes mGluR activation also induces expression of primary response genes, upregulates mRNA for growth factors, and alters expression of the glutamate transporter GLAST. EGF receptor activation also has a number of effects in these cells, including regulation of expression of the glutamate transporter GLT-1 as well as mGluRs 3 and 5 (Pechan et al., 1993; Miller et al., 1995; Yamaguchi and Nakanishi, 1998; Minoshima and Nakanishi, 1999; Gegelashvili et al., 2000; 
Zelenaia et al., 2000). However, the possible role of ERK2 in mediating these responses has not been investigated. Interestingly, pathological conditions, such as focal ischemia and epilepsy, exhibit profound changes in astrocytic morphologies and protein expression, including upregulation of mGluR5, EGF, and the EGF receptor (Planas et al., 1998; Rabchevsky et al., 1998; Aronica et al., 2000; Ulas et al., 2000). The combined increases in these proteins could increase the net MAP kinase response to extracellular glutamate in these pathological conditions.

\section{REFERENCES}

Adomeit A, Graness A, Gross S, Seedorf K, Wetzker R, Liebmann C (1999) Bradykinin $\mathrm{B}_{2}$ receptor-mediated mitogen-activated protein kinase activation in COS-7 cells requires dual signaling via both protein kinase $\mathrm{C}$ pathway and epidermal growth factor receptor transactivation. Mol Cell Biol 19:5289-5297.

Akiyama T, Ogawara H (1991) Use and specificity of genistein as inhibitor of protein-tyrosine kinases. Methods Enzymol 201:362-370.

Aronica E, van Vliet EA, Mayboroda OA, Troost D, da Silva FH, Gorter JA (2000) Upregulation of metabotropic glutamate receptor subtype mGluR3 and mGluR5 in reactive astrocytes in a rat model of mesial temporal lobe epilepsy. Eur J Neurosci 12:2333-2344.

Bence K, Ma W, Kozasa T, Huang XY (1997) Direct stimulation of Bruton's tyrosine kinase by $\mathrm{G}$-protein $\alpha$-subunit. Nature 389:296-299.

Berts A, Zhong H, Minneman KP (1999) No role for $\mathrm{Ca}^{2+}$ or protein kinase $\mathrm{C}$ in $\alpha-1 \mathrm{~A}$ adrenergic receptor activation of mitogen-activated protein kinase pathways in transfected PC12 cells. Mol Pharmacol 55:296-303.

Chang M, Zhang L, Tam JP, Sanders-Bush E (2000) Dissecting G-protein-coupled receptor signaling pathways with membranepermeable blocking peptides. Endogenous $5-\mathrm{HT}_{2 \mathrm{C}}$ receptors in choroid plexus epithelial cells. J Biol Chem 275:7021-7029.

Ciccarelli R, Sureda FX, Casabona G, Di Iorio P, Caruso A, Spinella F, Condorelli DF, Nicoletti F, Caciagli F (1997) Opposite influence of the metabotropic glutamate receptor subtypes mGlu3 and mGlu5 on astrocyte proliferation in culture. Glia 21:390-398.

Conn PJ, Pin JP (1997) Pharmacology and functions of metabotropic glutamate receptors. Annu Rev Pharmacol Toxicol 37:205-237.

Dale LB, Bhattacharya M, Anborgh PH, Murdoch B, Bhatia M, Nakanishi S, Ferguson SS (2000) G-protein-coupled receptor kinasemediated desensitization of metabotropic glutamate receptor 1A protects against cell death. J Biol Chem 275:38213-38220.

Daub H, Wallasch C, Lankenau A, Herrlich A, Ullrich A (1997) Signal characteristics of G-protein-transactivated EGF receptor. EMBO J 16:7032-7044

Della Rocca GJ, van Biesen T, Daaka Y, Luttrell DK, Luttrell LM, Lefkowitz RJ (1997) Ras-dependent mitogen-activated protein kinase activation by G-protein-coupled receptors. Convergence of $\mathrm{G}_{\mathrm{i}^{-}}$and $\mathrm{G}_{\mathrm{g}}$-mediated pathways on calcium/calmodulin, Pyk2, and Src kinase. J Biol Chem 272:19125-19132.

Della Rocca GJ, Maudsley S, Daaka Y, Lefkowitz RJ, Luttrell LM (1999) Pleiotropic coupling of G-protein-coupled receptors to the mitogen-activated protein kinase cascade. Role of focal adhesions and receptor tyrosine kinases. J Biol Chem 274:13978-13984.

Dingledine R, Borges K, Bowie D, Traynelis SF (1999) The glutamate receptor ion channels. Pharmacol Rev 51:7-61.

Doherty AJ, Palmer MJ, Henley JM, Collingridge GL, Jane DE (1997) $(R S)$-2-chloro-5-hydroxyphenylglycine (CHPG) activates mGlu5, but no mGlu1, receptors expressed in CHO cells and potentiates NMDA responses in the hippocampus. Neuropharmacology 36:265-267.

Ferraguti F, Baldani-Guerra B, Corsi M, Nakanishi S, Corti C (1999) Activation of the extracellular signal-regulated kinase 2 by metabotropic glutamate receptors. Eur J Neurosci 11:2073-2082.

Gasparini F, Lingenhohl K, Stoehr N, Flor PJ, Heinrich M, Vranesic I, Biollaz M, Allgeier H, Heckendorn R, Urwyler S, Varney MA, Johnson EC, Hess SD, Rao SP, Sacaan AI, Santori EM, Velicelebi G, Kuhn R (1999) 2-Methyl-6-(phenylethynyl)-pyridine (MPEP), a potent, selective and systemically active mGlu5 receptor antagonist. Neuropharmacology 38:1493-1503.

Gegelashvili G, Dehnes Y, Danbolt NC, Schousboe A (2000) The highaffinity glutamate transporters GLT1, GLAST, and EAAT4 are regulated via different signaling mechanisms. Neurochem Int 37:163-170.

Hall RA, Premont RT, Lefkowitz RJ (1999) Heptahelical receptor signaling: beyond the G-protein paradigm. J Cell Biol 145:927-932.

Hanke JH, Gardner JP, Dow RL, Changelian PS, Brissette WH, Weringer EJ, Pollok BA, Connelly PA (1996) Discovery of a novel, potent, and Src family-selective tyrosine kinase inhibitor. Study of Lckand FynT-dependent T-cell activation. J Biol Chem 271:695-701.

Heuss C, Scanziani M, Gahwiler BH, Gerber U (1999) G-proteinindependent signaling mediated by metabotropic glutamate receptors. Nat Neurosci 2:1070-1077.
Leserer M, Gschwind A, Ullrich A (2000) Epidermal growth factor receptor signal transactivation. IUBMB Life 49:405-409.

Levitzki A, Gazit A (1995) Tyrosine kinase inhibition: an approach to drug development. Science 267:1782-1788.

Litschig S, Gasparini F, Rueegg D, Stoehr N, Flor PJ, Vranesic I, Prezeau L, Pin JP, Thomsen C, Kuhn R (1999) CPCCOEt, a noncompetitive metabotropic glutamate receptor 1 antagonist, inhibits receptor signaling without affecting glutamate binding. Mol Pharmacol 55:453-461.

Liu M, Kirchgessner AL (2000) Agonist- and reflex-evoked internalization of metabotropic glutamate receptor 5 in enteric neurons. J Neurosci 20:3200-3205.

Luttrell LM, Hawes BE, van Biesen T, Luttrell DK, Lansing TJ, Lefkowitz RJ (1996) Role of c-Src tyrosine kinase in G-protein-coupled receptor- and $\mathrm{G} \beta \gamma$ subunit-mediated activation of mitogen-activated protein kinases. J Biol Chem 271:19443-19450.

Luttrell LM, van Biesen T, Hawes BE, Koch WJ, Krueger KM, Touhara K, Lefkowitz RJ (1997) G-protein-coupled receptors and their regulation: activation of the MAP kinase signaling pathway by G-proteincoupled receptors. Adv Second Messenger Phosphoprotein Res 31:263-277.

Luttrell LM, Daaka Y, Lefkowitz RJ (1999a) Regulation of tyrosine kinase cascades by G-protein-coupled receptors. Curr Opin Cell Biol 11:177-183.

Luttrell LM, Ferguson SS, Daaka Y, Miller WE, Maudsley S, Della Rocca GJ, Lin F, Kawakatsu H, Owada K, Luttrell DK, Caron MG, Lefkowitz RJ (1999b) $\beta$-Arrestin-dependent formation of $\beta_{2}$ adrenergic receptor-Src protein kinase complexes. Science 283:655-661.

Ma YC, Huang XY (1998) Identification of the binding site for $G_{q \alpha}$ on its effector Bruton's tyrosine kinase. Proc Natl Acad Sci USA 95:12197-12201.

Ma YC, Huang J, Ali S, Lowry W, Huang XY (2000) Src tyrosine kinase is a novel direct effector of G-proteins. Cell 102:635-646.

Maudsley S, Pierce KL, Zamah AM, Miller WE, Ahn S, Daaka Y, Lefkowitz RJ, Luttrell LM (2000) The $\beta_{2}$-adrenergic receptor mediates extracellular signal-regulated kinase activation via assembly of a multi-receptor complex with the epidermal growth factor receptor. J Biol Chem 275:9572-9580.

McCarthy KD, de Vellis J (1980) Preparation of separate astroglial and oligodendroglial cell cultures from rat cerebral tissue. J Cell Biol 85:890-902.

Miller S, Bridges RJ, Cotman CW (1993) Stimulation of phosphoinositide hydrolysis by trans- $( \pm)-\mathrm{ACPD}$ is greatly enhanced when astrocytes are cultured in a serum-free defined medium. Brain Res 618:175-178.

Miller S, Romano C, Cotman CW (1995) Growth factor upregulation of a phosphoinositide-coupled metabotropic glutamate receptor in cortical astrocytes. J Neurosci 15:6103-6109.

Minoshima T, Nakanishi S (1999) Structural organization of the mouse metabotropic glutamate receptor subtype 3 gene and its regulation by growth factors in cultured cortical astrocytes. J Biochem (Tokyo) 126:889-896.

Osherov N, Gazit A, Gilon C, Levitzki A (1993) Selective inhibition of the epidermal growth factor and HER2/neu receptors by tyrphostins. J Biol Chem 268:11134-11142.

Peavy RD, Conn PJ (1998) Phosphorylation of mitogen-activated protein kinase in cultured rat cortical glia by stimulation of metabotropic glutamate receptors. J Neurochem 71:603-612.

Pebay A, Torrens Y, Toutant M, Cordier J, Glowinski J, Tence M (1999) Pleiotropic effects of lysophosphatidic acid on striatal astrocytes. Glia 28:25-33.

Pechan PA, Chowdhury K, Gerdes W, Seifert W (1993) Glutamate induces the growth factors NGF, bFGF, the receptor FGF-R1, and c-fos mRNA expression in rat astrocyte culture. Neurosci Lett 153:111-114.

Planas AM, Justicia C, Soriano MA, Ferrer I (1998) Epidermal growth factor receptor in proliferating reactive glia following transient focal ischemia in the rat brain. Glia 23:120-129.

Prenzel N, Zwick E, Daub H, Leserer M, Abraham R, Wallasch C, Ullrich A (1999) EGF receptor transactivation by G-protein-coupled receptors requires metalloproteinase cleavage of proHB-EGF. Nature 402:884-888.

Rabchevsky AG, Weinitz JM, Coulpier M, Fages C, Tinel M, Junier MP (1998) A role for transforming growth factor $\alpha$ as an inducer of astrogliosis. J Neurosci 18:10541-10552.

Rankin ML, Alvania RS, Gleason EL, Bruch RC (1999) Internalization of G-protein-coupled receptors in single olfactory receptor neurons. J Neurochem 72:541-548.

Sallese M, Iacovelli L, Cumashi A, Capobianco L, Cuomo L, De Blasi A (2000) Regulation of G-protein-coupled receptor kinase subtypes by calcium sensor proteins. Biochim Biophys Acta 1498:112-121.

Schinkmann KA, Kim TA, Avraham S (2000) Glutamate-stimulated activation of DNA synthesis via mitogen-activated protein kinase in primary astrocytes: involvement of protein kinase $\mathrm{C}$ and related adhesion focal tyrosine kinase. J Neurochem 74:1931-1940. 
Seo B, Choy EW, Maudsley S, Miller WE, Wilson BA, Luttrell LM (2000) Pasteurella multocida toxin stimulates mitogen-activated protein kinase via $\mathrm{G}_{\mathrm{q} / 11}$-dependent transactivation of the epidermal growth factor receptor. J Biol Chem 275:2239-2245.

Siciliano JC, Gelman M, Girault JA (1994) Depolarization and neurotransmitters increase neuronal protein tyrosine phosphorylation. J Neurochem 62:950-959.

Siciliano JC, Toutant M, Derkinderen P, Sasaki T, Girault JA (1996) Differential regulation of proline-rich tyrosine kinase $2 /$ cell adhesion kinase $\beta(\mathrm{PYK} 2 / \mathrm{CAK} \beta)$ and pp $125^{\mathrm{FAK}}$ by glutamate and depolarization in rat hippocampus. J Biol Chem 271:28942-28946.

Soltoff SP (1998) Related adhesion focal tyrosine kinase and the epidermal growth factor receptor mediate the stimulation of mitogenactivated protein kinase by the G-protein-coupled P2Y2 receptor.
Phorbol ester or $\left[\mathrm{Ca}^{2+}\right]_{\mathrm{i}}$ elevation can substitute for receptor activation. J Biol Chem 273:23110-23117.

Ulas J, Satou T, Ivins KJ, Kesslak JP, Cotman CW, Balazs R (2000) Expression of metabotropic glutamate receptor 5 is increased in astrocytes after kainate-induced epileptic seizures. Glia 30:352-361.

Yamaguchi S, Nakanishi S (1998) Regional expression and regulation of alternative forms of mRNAs derived from two distinct transcription initiation sites of the rat mGluR5 gene. J Neurochem 71:60-68.

Zelenaia O, Schlag BD, Gochenauer GE, Ganel R, Song W, Beesley JS, Grinspan JB, Rothstein JD, Robinson MB (2000) Epidermal growth factor receptor agonists increase expression of glutamate transporter GLT-1 in astrocytes through pathways dependent on phosphatidylinositol 3-kinase and transcription factor NF- $\kappa \beta$. Mol Pharmacol 57:667-678. 